\title{
Plant Patenting: A Public Fruit Breeder's Assessment
}

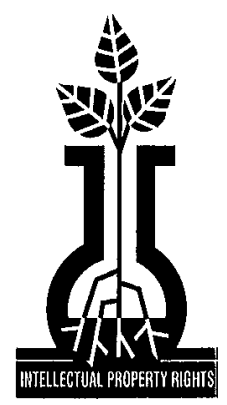

James N. Moore ${ }^{1}$

Additional index words. plant proprietary rights, utility patents, trademarks, fruit breeding, fruit cultivars

Summary. The strategy of plant patenting as a means to generate research funds is gaining increasing interest in fruit breeding programs in public institutions. Patenting can be a positive force in maintaining fruit breeding programs if applied to superior cultivars and supported by well-designed licensing and distribution procedures. To qualify for a plant patent, a cultivar must be distinct, new, and asexually propagated, and cannot be in public use or on sale more than 1 year prior to the application for patent. Plant patents provide protection only for the whole plant as described. In contrast, utility patents can be obtained to provide proprietary rights to individual plant genes, plant characteristics, and plant products. The possible impact of utility patents on future fruit breeding programs is discussed.

厂

n 1930, after many years of debate, the U.S. Congress enacted the Townsend-Purnell Plant Patent Act, which states, "Whoever invents or discovers and asexually reproduces any distinct and new variety of plant, including cultivated sports, mutants, hybrids, and new found seedlings, other than a tuber propagated plant or a plant found in an uncultivated state, may obtain a patent therefor,. . .".

A plant patent provides that the patent holder has the exclusive right to asexually reproduce and sell the patented variety for a period of 17 years. The noted fruit breeder Luther Burbank was a strong advocate of plant patenting. In committee, Congressman Purnell quoted Burbank's writings on cultivar protection, one of which stated: "A man can patent a mousetrap or copyright a nasty song, but if he gives to the world a new fruit that will add millions to the value of earth's annual harvests, he will be fortunate if he is rewarded by so much as having his name connected with the result." (Janick et al., 1983). 
The enactment of the Plant Patent Act greatly stimulated the breeding and development of asexually reproduced plants, including fruit crop species, among private breeders because, for the first time, they had a mechanism for protecting their investments in new variety development. The utilization of plant patents was not adopted immediately by public plant breeding institutions, such as state agricultural experiment stations and the USDA. In fact, only in recent years has plant patenting been pursued by a few experiment stations, while many still shun the process.

The debate still continues on the propriety of public institutions to patent plants. Opponents point to ethical (development with public funds) and professional (limiting germplasm exchange) reasons to avoid patenting. Proponents dismiss these arguments on the grounds that only users of the new cultivars pay for their development and that patenting does not necessarily restrict germplasm exchange. An overriding argument in favor of plant proprietary protection by public institutions has emerged in the past decade. That is, if breeding programs are to survive, they must generate funds to pay most of the cost of the programs (Janick et al., 1983). This fact has prompted many public institutions to reconsider the advantages of proprietary plant protection.

While the generation of funds from royalty fees is an important result of plant patenting, there are other advantages to patenting superior genotypes of plants. A plant patent establishes ownership of a plant cultivar, and, as such, provides deserved credit to the inventor of that cultivar. Patents also allow inventors to govern the distribution and use of their plant inventions.

U.S. plant patents are administered by the Patent and Trademark Office, an agency of the U.S. Dept. of Commerce, in contrast to the Plant Variety Protection program for seed-propagated plants, which is administered by the USDA.

Applications for plant patents are made to the Commissioner of Patents and Trademarks and must follow the format of all patent applications: 1) a written document comprising a specification (description and claims) and an oath or declaration; 2) a drawing (or photograph) depicting the characteristics of the new variety; and 3) the filing fee. The specification must be framed in specific order of arrangement: 1) title of invention (cultivar name); 2) brief summary of invention; 3 ) brief description of the drawings (or photographs); 4) detailed description; 5) claim or claims; and 6) abstract of the disclosure. The entire application must adhere to specific preparation guidelines, spelled out in publications obtainable from the Patent and Trademark Office.
Plant patent applications should include a complete detailed description of the characteristics of the plant, expressed in botanical terms, that distinguish it to the extent possible from other cultivars of the species. The distinction may include biochemical differences as well as morphological differences. The application also must include the origin of the new plant and state the manner in which it has been asexually reproduced. If color is a distinctive feature of the plant, the color should be stated in reference to a recognized color dictionary.

In addition to the specified origin, novelty, and asexual reproduction of a plant, the variety must be new, in the sense ofutilization and publication of its characteristics. The patent statute states that the invention (plant variety) cannot be patented if "The invention was patented or described in a printed publication in this or a foreign country or in public use or on sale in this country more than one year prior to the application for patent in the United States...". (U.S. Dept. of Commerce, 1980).

It has been held, however, that a printed publication, which would bar a utility patent, is not a bar to a plant patent on the ground that a publication is nonenabling for a plant (Seay, 1993). The public use or sale of the plant more than 1 year prior to patent application is a bar to plant patent issue in the United States.

The costs of plant patenting are reasonable. Nonprofit organizations, such as universities, may be assessed reduced charges upon filing a declaration claiming small entity status. Nevertheless, the commercial potential of the new cultivar should be assessed to determine if patenting is warranted. This usually is accomplished by controlled testing over a wide geographic area prior to naming and patenting.

The time period between the filing of a plant patent application and the examiner's determination may range from 6 to 18 months. The protection afforded by a patent does not start until the actual grant of the patent. Some breeders, and their licensed nurseries, mark plants sold prior to actual patent issue as "patent pending" or "patent applied for," but these terms have no legal basis of protection.

All patented plants sold should be labeled clearly with the words "U.S. Plant Patent" followed by the patent number, and breeders licensing nurseries to propagate and sell their patented cultivars should require that such labeling be done. Otherwise, the patent holder may have difficulty in recovering damages from an infringer who was not duly informed of the protected status of the cultivar.

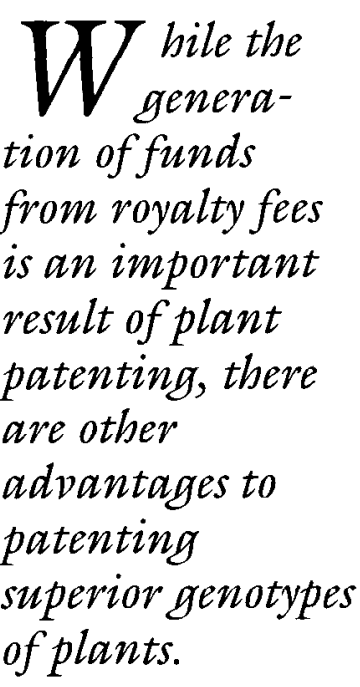


Tt should be the

goal to choose a

licensing system

that will expose

the new cultivar

to the most rapid

and widespread

distribution, both

from the

standpoint of

greater return of

royalties and for

the greater public

good.
A plant patent is personal property and may be sold or assigned to others. Most universities have a patent policy, usually requiring that patentable items be assigned by employees to the university if the inventions were made on university time and expense. The university then may assign a portion of royalties from the invention to the inventor. The university also may return a portion of royalties to the research program that generated the invention to fund further research in that area.

After a plant patent has been obtained, the breeder and the university must determine the best method to commercialize the new cultivar. A few universities have propagation facilities, or plant materials components, capable of multiplying and selling plants to growers. However, most universities choose to issue licenses to commercial nurseries for propagation and sale of patented cultivars. Licensing can be either exclusive (to one nursery) or non-exclusive (to a number of nurseries). There are advantages and disadvantages for both systems, and the choice may depend on the type of plant cultivar being commercialized, the number and size of nurseries propagating the plant type, and the scope of the potential market. It should be the university's goal to choose a licensing system that will expose the new cultivar to the most rapid and widespread distribution, both from the standpoint of greater return of royalties and for the greater public good. At the Univ. of Arkansas, we usually issue nonexclusive licenses to reputable U.S. nurseries, in which we select local, regional, and national nurseries to propagate the new cultivar. For foreign patents, we usually issue exclusive licenses (see later section on foreign patents).

Licensing contracts with nurseries should be in the form of a legally binding document. The contract should state clearly and concisely the conditions of propagation and sale required by the patent holder. Some such conditions might include the maintenance of the germplasm to ensure trueness to name, plant health, etc. Labeling requirements as to the protected status of the cultivar should be stated clearly and enforced. Any conditions required for sales to other nurseries or retailers should be listed. The amount of royalty fee should be stated, along with the time and method of making royalty payments. Conditions for possible termination of the contract by either party should be specified.

The plant patent grant confers to the patent holder "the right to exclude others from making, using or selling" the patented cultivar for a period of 17 years. While federal law backs the protection given by a plant patent, the actual monitoring of violations must be done by the patent holder or its licensees. Violations of plant patents usually take one of two forms: 1) disreputable nurseries knowingly propagating and selling patented plants, or 2) growers propagating patented cultivars to increase their plantings. Unfortunately, it is a common belief among fruit growers in the United States that the plant patent law is only applicable to selling patented plants, and that multiplying plants for one's own use is legal. In fact, such multiplication is the same violation as illegally propagating for sale, but it is difficult to monitor. In our program, we monitor illegal nursery propagation by annually requesting sources of plants from all retail sources known to advertise our patented cultivars for sale. Response has been good, and we have uncovered some violations.

University of Arkansas licensing contracts specify that the obligation for paying royalties lies with the licensed nursery that propagates the plants for first sale. Thus, if one licensed nursery sells to another licensed nursery for resale, the royalties are the responsibility of the nursery propagating the plants. We require that each licensed nursery provide us with an accounting of plants sold each year. Most do this by sending copies of computer printouts of individual sales for the year. While there may be some slippage in the enforcement of our plant patents, nursery violations are kept to a minimum by selecting honest, reputable nurseries for licensing and by monitoring mail-order outlets.

\section{Foreign plant patents}

Many good fruit cultivars prove to be widely adapted and often are grown commercially in countries outside the United States. Because the proprietary rights granted by a U.S. patent extend only throughout the territory of the United States and have no legal standing in foreign countries, the breeder of a new fruit cultivar may wish to apply for plant patents in countries in which the cultivar may be used. The patent laws and requirements for patent application vary greatly among countries and must be determined in advance of submitting an application for patent.

Many countries now follow the standard guidelines and procedures for granting breeders' rights developed in 1961 by the International Convention for the Protection of New Varieties of Plants (revised 1972, 1978, 1991) (UPOV, 1991). Breeders desiring protection for a new plant cultivar in a foreign country should ascertain if that country is a signatory to UPOV, and then follow the established procedures for applying for variety protection. UPOV allows the filing of a foreign application for 4 years (6 years for trees and vines) after the date of first commercial sale or 
use of the variety authorized by the breeder. This time bar is less restrictive than for domestic patents, for which application must be made within 1 year of date of first use. Additional information on UPOV regulations and a list of convention countries can be obtained from UPOV, POB 18, 1211 Geneva 20, Switzerland (fax 41-22-733-5428). The U.S. representative to UPOV is Dieter H. Hoinkes, U.S. Dept. of Commerce, Commissioner of Patents and Trademarks, Office of Legislation and International Affairs, P.O. Box 4, Washington, DC 20231.

One approach to foreign patenting of fruit cultivars is to enter into an exclusive contractual agreement with a reliable nursery in the foreign country, with the nursery securing variety protection in that country. The nursery then recovers their legal fees from the exclusive right to propagate and sell the cultivar in that country and remits the specified royalties to the breeder. Most such nurseries insist on prerelease testing of the plant cultivar to assure good marketability in their country. This testing can be done under a legally binding testing agreement.

A similar system may be used in the United States whereby breeders of asexually propagated plant cultivars enter into agreement to sell their rights to a new cultivar to a U.S. nursery. The nursery then prepares and files the plant patent application in the name of the originator, who assigns the patent to the nursery. The nursery pays all costs of patenting, assumes responsibility for enforcement, and pays royalties to the breeder (Hutton, 1991).

\section{Trademarks}

Trademarking is a form of proprietary protection indicating source or origin. Unlike a plant patent, which excludes others from propagating a plant cultivar for 17 years, the life of a trademark can be indefinite. Today we are seeing more and more trademarks used in the marketing of fruit cultivars.

Trademarks have been misunderstood and, in some cases misused, leading to confusion in the nursery trade (Darke, 1991). A trademark is intended to indicate origin or source of a plant cultivar and cannot be the name of the cultivar. For this reason, nursery catalogs may use a trademark for marketing purposes, while clearly listing the proper cultivar name. For example, Stark Bros. catalog lists Starkspur® UltraMac ${ }^{\mathrm{TM}}$ (Dewar cultivar) apples, thus presenting both a trademark and a cultivar name. When the plant patent expires on this apple after 17 years, Stark Bros. will have no control over the propagation and sale of the Dewar cultivar, but they will still have legal right to exclude others from using the trademark Starkspur ${ }^{\circledR}$ or UltraMac ${ }^{\mathrm{TM}}$ to market any fruit tree variety. To fruit breeders and nurseries, a strong valid trademark is an increasingly important marketing mechanism, particularly after the patent has expired and the plant can be propagated freely by every one (Elliott, 1991).

Confusion in the use of trademarks for plant cultivars is created when trademark names are made to appear as cultivar names, sometimes even being enclosed in single quotes, generally interpreted as a cultivar name (Darke, 1991). When a trademark is used in the marketing of a single cultivar, the trademark always should be used in association with the cultivar name (Elliott, 1991). A second problem occurs when trademarks that were used previously as well-established cultivar names are used (Darke, 1991).

A good review of the use and misuse of trademarks in plant property rights was published recently by Elliott (1991).

\section{Utility patents}

The 1930 Plant Patent Act provides protection only for the whole plant as described. In 1985, the U.S. Patent Office Board of Patent Appeals and Interferences ruled that the general Patent Act (the utility patent) could be used to provide proprietary rights for individual plant genes, gene combinations, plant characteristics, plant products, and many other types of claims (Brooks, 1990).

The extension of the utility patent to plants has resulted in concern and speculation among plant breeders as to its effect on plant cultivar development. Under the 1930 Act the sexual reproduction of patented cultivars is not an infringement, nor is any biological material derived from sexual reproduction of the plant. In contrast, it appears that the utility patent may prohibit the transfer of individual protected genes or characteristics via sexual breeding (Brooks, 1990). Further, the patenting of specific plant traits could greatly restrict plant breeding programs and affect adversely the free exchange of germplasm that is the lifeblood of plant cultivar development. Whether these concerns become reality will be determined by future experience with utility patents as applied to plant germplasm.

\section{Conclusions and perspective}

The patenting of new fruit cultivars developed by public institutions is a viable strategy for generating research funds to support the continuation of fruit breeding programs. During the past decade, several state university fruit breeding programs have been discontinued due to lack of support funds. As state and federal support for public institutional research continues to decline, many

\section{7 be patent- 1 ing of new fruit cultivars developed by pub- lic institutions is a viable strategy for generating research funds to support the continuation of fruit breeding programs.}




\section{$T$ be continu- ation of pub- lic fruit breeding programs is criti- cal to the continued well- being of the fruit industries of the United States.}

more programs are in jeopardy and likely will be lost, The loss of public fruit breeding programs has serious consequences for fruit growers and consumers alike. Unlike most seed-propagated crop species, private industry is not likely to fill the void in the breeding of fruit species. The high investments required in land space and labor, coupled with the long generation cycle of fruit species, does not encourage private development of most species. Furthermore, only public institutions have the staff and other resources to support the kind of interdisciplinary research (biotechnology, plant pathology, entomology, food science, etc.) that is needed to support plant breeders in the development of successful fruit cultivars for the future. Another often overlooked concern is the training of future plant breeders. If university plant breeding programs cease to exist, who will train the plant breeders for private industry? Plant breeding is both an art and a science. I am convinced that students of plant breeding can be prepared for successful careers only by being trained in active, successful breeding programs. Therefore, universities have an obligation to society not only to produce new plant cultivars needed for the future, but also to educate plant breeding professionals to continue the work.

Based on these stated philosophies, it is apparent that the continuation of public plant breeding programs is for the public good. Specifically, the continuation of public fruit breeding programs is critical to the continued well- being of the fruit industries of the United States. Plant patenting is a mechanism available to supplement declining public funds for plant breeding programs and to rescue some programs from oblivion.

While plant patents can be a positive force in public plant breeding programs, the widespread use of utility patents, based on current interpretation of the law, could prove to be disastrous to plant breeding progress. If public plant breeding is to meet the industry needs of the future, the traditional philosophy among breeders of free exchange of germplasm and information must be maintained. Any interference in this operating principle would not be in the best interest of society.

\section{Literature Cited}

Brooks, H.J. 1990. Introduction. Genetic resources of temperate fruit and nut crops. Acta Hort. 290:xi-xvi.

Darke, R. 1991. A curator's viewpoint. HortScience 26:362-363

Elliott, W.H., Jr. 1991. Property rights and plant germplasm. Hortscience 26:364-365.

Hutton, R.J 1991. New funds for plant breeding. HortScience 26:361-362.

Janick, J., R.E. Bagwill, and J.R. Nesbitt 1983. Cultivar release and protection, p. 383-397. In: J.N. Moore and J. Janick (eds.). Methods in fruit breeding. Purdue Univ. Press, W. Lafayette, Ind.

Seay, N.J. 1993. Intellectual property rights in plants. Intellectual property rights: Protection of plant material. ASA Spec. Publ. (In press.)

UPOV. 1991. International convention for the protection of new varieties of plants. UPOV Publ. No. 221(E).

U.S. Dept. of Commerce. 1980. General information concerning patents. U.S. GPO, Washington, D.C. 1980 0-327-741. 